Volume 1 Issue 1, Juni 2019

http:/ / ejournal.unsub.ac.id/index.php/keuangan

\title{
Prosedur Pemberian Kredit Pada PT. BPR Karya Utama Jawa Barat Cabang Pagaden
}

\author{
Ine Mariane \\ FISIP Universitas Pasundan \\ inemariane@unpas.co.id
}

\begin{abstract}
Abstrak
PT.BPR KARYA UTAMA JABAR CABANG PAGADEN didirikan bertujuan untuk memperluas layanan kepada masyarakat lebih tercapai, membangun peningkatan pendapatan masyarakat khususnya dipedesaan melalui kegiatan usaha menghimpun dana masyarakat dan menyalurkan dalam bentuk kredit bagi masyarakat. Staf kredit adalah petugas Bank yang menangani pemberian kredit kepada calon nasabah baru dan nasabah lama. Staf kredit merupakan suatu bagian yang sangat penting dalam organisasi Bank karena posisi staf kredit adalah dimana keuntungan Bank ada didalam kredit, dilihat dari fungsi dan tanggungjawab staf kredit dalam melaksanakan pekerjaan cukup berat karena ada target tersendiri untuk pemenuhan nasabah baru.
\end{abstract}

Kata kunci : Pelayanan

\section{Abstract}

PT. BPR KARYA UTAMA JABAR branch of PAGADEN was established aiming to expand services to the more established community, build an increase in income especially in rural communities through the business activities of collecting public funds and channeling in the form of credit to the community. Credit staff are bank officers who handle lending to prospective new customers and old customers. Credit staff is a very important part in the bank organization because the credit staff position is where the bank's profit is in credit, seen from the functions and responsibilities of the credit staff in carrying out quite heavy work because there are separate targets for the fulfillment of new customers.

Keywords: Services 


\section{Pendahuluan}

Bank merupakan lembaga keuangan atau perusahaan yang bergerak di bidang keuangan sebagai lembaga keuangan bank melakukan kegiatan pokok di bidang keuangan artinya usaha perbankan selalu berkaitan dengan keuangan. Pertumbuhan perekonomian Indonesia dalam tahun-tahun terakhir ini sedang mengalami perkembangan yang sangat pesat. Bentuk-bentuk usaha yang baru banyak bermunculan dengan upaya untuk mencari keuntungan. Para pelaku usaha ini sangat penting perannya dalam mengurangi tingkat pengangguran dengan cara membuka lapangan pekerjaan ke masyarakat luas. Pertumbuhan dunia perbankan ini berkembang pesat, terbukti dengan ramainya perusahaan-perusahaan yang bergerak di bidang perbankan walaupun keadaan perbankan saat ini banyak juga bank yang mengalami likuidasi. Keberadaan bank sebagai lembaga keuangan mempunyai peranan yang cukup penting dalam mensukseskan pelaksanaan pembangunan. Bank sangat diharapkan mampu melakukan produk jasa bank bagi pembangunan, disamping berbagai jenis produk jasa lainnya yang ditawarkan kepada masyarakat. Bank dalam memberikan kredit menggunakan prinsip kehati-hatian dalam memberikan pelayanannya, karena pihak bank tidak mau mengambil resiko kegagalan dalam pelunasan kredit para debitur, yang kita kenal dengan istilah kredit macet. Kredit macet akan membawa dampak tidak baik bagi kelangsungan bank itu sendiri, dan masyarakat akan mulai mempertanyakan kredibilitas bank tersebut.

Prinsip kehati-hatian dalam menganalisis permohonan kredit itu sangat diperlukan. Pihak bank dapat memberikan kredit tersebut dengan baik dan benar maka tingkat resiko dan kerugian dapat ditekan sekecil mungkin, akan tetapi sebaliknya apabila pihak bank tidak dapat melakukan dengan baik dan benar maka akan terjadi penyimpangan dalam pemberian kredit yang dilakukan oleh calon debitur yang megajukan kredit, sehingga hal ini bisa mengakibatkan terjadinya kredit macet, maka bank pun mendapat kerugian di segi pinjamannya dan pandangan masyarakat atas kredibilitas bank tersebut. Perkembangan Bank saat ini sudah semakin luasnya demikian juga dengan wilayah operasinya sehingga untuk mempermudah kegiatan dan penghimpunan dana maka setiap daerah mendirikan bank dalam rangka meningkatkan ekonomi dan pembangunan masing-masing daerah tersebut. Dengan melihat uraian diatas maka penulis tertarik untuk

\section{Kerangka Teori}

\section{a. Pengertian Administrasi}

Menurut Siagian (2001:2) administrasi adalah sebagai "keseluruhan proses kerjasama antara dua orang atau lebih yang didasarkan atas rasionalitas tertentu dalam rangka pencapaian tujuan yang telah ditentukan sebelumnya dengan memanfaatkan saran dan prasarana tertentu secara berdaya guna dan berhasil guna". 
Administrasi dapat diartikan dalam arti sempit dan luas. Handayaningrat (1998:2) mengatakan bahwa " administrasi dalam arti sempit yang meliputi kegiatan catat mencatat, surat menyurat, pembukuan ringan, ketik mengetik, agenda dan sebagainya yang bersifat teknis ketatausahaan". Sedangkan dalam arti luas dapat disimpulkan pada dasarnya mengandung unsure pokok yang sama yaitu adanya kegiatan tertentu, adanya manusia yang melakukan kerjasama serta mempunyai tujuan ditentukan sebelumnya.

Selanjutnya Pasolong (2010:3) mendefinisikan administrasi adalah pekerjaan terencana yang dilakukan oleh sekelompok orang dalam bekerjasama untuk mencapai tujuan atas dasar efektif, efisien dan rasional.

Adapun tujuan dari administrasi adalah menerapkan kemampuan dan keterampilan kerja sehingga tercapai tujuan secara efektif dan efisien melalui tindakan rasional.

\section{b. Prosedur}

Prosedur tidak hanya melibatkan aspek finansial saja, tetapi aspek manajemen juga memiliki peranan penting, prosedur merupakan rangkaian langkah yang dilaksanakan untuk menyelesaikan kegiatan atau aktifitas sehingga dapat tercapai tujuan yang diharapakan secara efektif dan efisien serta dapat dengan mudah menyelesaikan suatu masalah yang terperinci menurut waktu yang ditetapkan. Untuk memberikan gambaran yang lebih jelas, penulis mengungkapkan beberapa pendapat tentang pengertian prosedur, diantaranya pengertian yang dikemukakan oleh Kasmir (2000;15) mendefinisikan prosedur sebagai berikut: "Prosedur adalah suatu urutan kegiatan, biasanya melibatkan beberapa orang dalam suatu departemen atau lebih yang dibuat untuk menjamin penanganan secara seragam transaksi perusahaan yang terjadi secara berulang-ulang". Dari beberapa pengertian diatas maka dapat ditarik kesimpulan bahwa pengertian prosedur suatu urutan tugas pekerjaan yang saling berhubungan satu sama lain dalam rangka pencapaian tujuan. Prosedur yang baik mempunyai beberapa karakteristik, diantaranya sebagai berikut:

1) Prosedur menunjang tercapainya suatu organisasi

2) Prosedur mampu menciptakan adanya pengawasan yang baik dan menggunakan biaya yang seminimal mungkin.

3) Prosedur menunjukan urutan-urutan yang logis dan sederhana

4) Prosedur menunjukan adanya penetapan keputusan dan tanggungjawab

5) Menunjukan tidak adanya penetapan keputusan dan tanggungjawab

6) Adanya suatu pedoman kerja yang harus diikuti oleh anggota-anggota organisasi.

7) Mencegah terjadinya penyimpangan.

8) Membantu efisiensi, efektifitas dan produktifitas kerja dari suatu unit organisasi. 
Volume 1 Issue 1, Juni 2019

http:/ / ejournal.unsub.ac.id/index.php/keuangan

c. Bank

\section{c.1 Pengertian Bank}

Untuk lebih memahami pengertian tentang lembaga perbankan menurut Kasmir (2000:11) "Bank adalah lembaga keuangan yang kegiatan utamanyaadalah menghimpun dana dari masyarakatdan menyalurkan kembali dana tersebut kemasyarakatanserta memberikan jasa Bank lainnya". Menurut Undang-Undang No.10 Tahun 1998 yang dimaksud dengan Bank adalah badan usaha yang menghimpun dana dari masyarakat dalam bentuk simpanan dan menyalurkannya kepada masyarakat dalam bentuk kredit atau bentuk lainnya dalam rangka meningkatkan taraf hidup rakyat banyak. Bank merupakan lembaga keuangan atau perusahaan yang bergerak dibidang keuangan, sebagai lembaga keuangan Bank melakukankegiatan pokok dibidang keuangan, maka secara garis besar usaha perbankan selalu berkaitan dengan keuangan. Dalam praktik perbankan di Indonesia saat ini yang diatur dalam Undang-Undang perbankan memiliki beberapa jenis Bank. Didalam Undang-Undang No.10 Tahun 1998 dengan sebelumnya yaitu Undang-Undang No. 14 Tahun 1967, terdapat beberapa perbedaan jenis perbankan.

Dalam Undang-Undang pokok perbankan no.14 Tahun 1967 tersebut jenis perbankan menurut fungsinya terdiri dari :

1) Bank Umum

2) Bank Pembangunan

3) Bank Tabungan

4) Bank Pasar

5) Bank Desa

6) Lembaga Desa

7) Bank pegawai

Berdasarkan Undang-Undang Pokok Perbankan Nomor 7 Tahun 1992 dan ditegaskan lagi dengan keluarnya Undang-Undang Republik Indonesia Nomor 10 Tahun 1998 maka jenis perbankan terdiri dari 2 jenis : Bank Umum dan Bank Perkreditan Rakyat.

Berdasarkan Undang-Undang Nomor 7 Tahun 1992 tersebut mengakibatkan perubahan fungsi Bank Pembangunan dan Bank Tabungan menjadi Bank Umum. Kemudian Bank Desa, Bank Pasar, Lembaga Desa dan Bank Pegawai menjadi Bank Perkreditan Rakyat. Pengertian Bank Umum sesuai dengan Undang-Undang Nomor 10 Tahun 1998 adalah Bank yang melaksanakan kegiatan usaha secara konvensional atau berdasarkan prinsip syariah yang dalam kegiatannya memberikan jasa dalam lalu lintas pembayaran sedangkan Bank Perkreditan Rakyat adalah Bank yang melaksanakan kegiatan usaha secara konvensional dan atau berdasarkan prinsip syariah yang dalam kegiatannya tidak memberikan jasa dalam lalu lintas pembayaran. Dari Pengertian tersebut kegiatan BPR jauh lebih sempit dibandingkan dengan kegiatan Bank Umum. Kegiatan BPR hanya meliputi kegiatan penghimpun dan penyaluran dana saja. Bahkan dalam menghimpun dana BPR dilarang untuk menerima simpanan giro larangan lainnya bagi BPR adalah 
tidak diperkenankan ikut kliring serta transaksi valuta asing. Disamping kedua jenis Bank diatas dalam praktiknya masih terdapat satu lagi jenis Bank yang ada di Indonesia yaitu Bank Sentral, jenis Bank ini bersifat tidak komersil seperti halnya Bank Umum dan BPR. Di Indonesia fungsi Bank Sentral dipegang oleh Bank Indonesia. Fungsi Bank Sentral adalah sebagai Bank sirkulasi, Bank to Bank dan Ledder Of The Laast.

Jenis Bank dapat dilihat dari berbagai segi, yaitu :

1) Dilihat dari segi kepemilikannya

Jika dilihat dari segi kepemilikannya maka Bank terbagi menjadi Bankmilik pemerintah, Bank milik swasta nasional, Bank milik koperasi, Bank asing dan Bank milik campuran.

2) Dilihat dari segi status

Jika dilihat dari segi status maka Bank terdiri dari Bank yang dapat melaksanakan transaksi keluar negeri atau yang berhubungan dengan mata uang asing (Bank Devisa) dan Bank belum dapat mempunyai izin untuk melaksanakan transaksi sebagai Bank devisa (bank non devisa).

3) Dilihat dari segi caramenentukan harga

Dalam menentukan harga,baik harga jual maupun harga belisaat ini Bank terbagi kedalam 2 kelompok yaitu Bank konvensional dan Bank yang berdasarkan prinsip syariah (Islam).

Perkembangan Bank saat ini sudah semakin luasnya, dengan demikian juga dengan wilayah operasinya sehingga untuk mempermudah kegiatan dan penghimpunan dana maka setiap daerah mendirikan Bank dalam rangka meningkatkan ekonomi dan pembangunan masing-masing daerah.

\section{c.2 Ruang Lingkup Bank/Perbankan}

Pengertian Bank Umum menurut Undang-Undang Nomor 10 Tahun 1998 : “ Bank umum adalah Bank yang melaksanakan kegiatan usaha secara konvensional atau berdasarkan prinsip syariah yang dalam kegiatannya memberikan jasa dalam lalu lintas pembayaran". Peranan Bank antara lain adalah :

1) Sebagai Lembaga Keuangan

Bank sebagai lembaga keuangan memiliki fungsi sebagai lembaga intermediasi antara pihak yang memiliki kelebihan likuiditas Bank itu dunia usaha, pemerintah dan rumah tangga dengan pihak yangmengalami kekurangan likuiditas yaitu dunia usaha, pemerintah dan rumah tangga. Peran sebagai intermediasi inilah yang membuat Bank sangat berperan dalam mendukung segala kegiatan ekonomi suatu Negara dalam pendapatannya dana yang dikumpulkan dan pihak Bank yang memiliki kelebihan likuiditas tersebut akan disalurkan kemnbali oleh Bank kepada pihak yang mengalami kekurangan likuiditas dalam proses penyaluran tersebut Bank harus melakukan berbagai proses yang mesti dilakukan supaya dana yang disalurkan dapat memberikan hasil baik bagi Bank maupun nasabah yang menyimpan dananya di Bank.

2) Sebagai Lembaga Moneter 
Perekonomian yang stabil akan lebih disukai dibandingkan dengan perekonomian yang mengalami gejolak dan guncangan. Kestabilan menjadi sangat penting karena kondisi stabil akan menciptakan suasana yang kondusif untuk perkebangan dunia usaha dan bisnis. Salah satu parameter yang dapat mengukur kestabilan perekonomian yakni dengan melihat kinerja dan stabilitas makro ekonomi.

Fungsi-fungsi Bank umum yang diuraikan dibawah ini menunjukan betapa pentingnya keberadaan Bank umum dalam perekonomian modern yaitu ;

1) Penciptaan uang

2) Mendukung kelancaran mekanisme pembayaran

3) Menghimpun dana simpanan masyarakat

4) Mendukung kelancaran transaksi internasional

5) Penyimpanan barang-barang berharga

6) Pemberian jasa-jasa lainnya.

\section{c.3 Usaha Bank}

Menurut Pasal 6, usaha Bank umum meliputi :

a) Menghimpun dana dari masyarakat dalam bentuk simpanan berupa giro, deposito berjangka, sertifikat deposito, tabungan, dan bentuk lainnya yang dipersamakan dengan itu.

b) Memberikan kredit

c) Memberikan surat pengakuan utang

Membeli, menjual atau menjamin atas resiko sendiri maupun kepentingan atas perintah Nasabahnya : Surat-surat wesel termasuk wesel yang diakseptasi oleh Bank yang masa berlakunya tidak lebih lama dari pada kebiasaan dalam perdagangan surat-surat dimaksud

Surat pengakuan utang dan kertas dagang lainnya yang masa berlakunya lebih lama dari kebiasaan dalam perdagangan surat-surat dimaksud : Kertas pembendaharaan Negara dan surat jaminan pemerintahan : Sertipikat Bank Indonesia Obligasi; Surat dagang berjangka waktu dengan 1 tahun, instrumen surat berharga lain yang berjangka waktu sampai dengan 1 tahun.

d) Memindahkan uang baik untuk kepentingan sendiri maupun untuk kepentingan nasabah.

e) Menempatkan dana pada, meminjamkan dana dari, atau memindahakan dana kepada Bank lain, baik dengan menggunakan surat, sarana telekomunikasi maupun wesel untuk cek atau sarana lainnya.

f) Menerima pembayaran dari tagihan atas surat berharga dan melakukan perhitungan dengan atau antar pihak ketiga.

g) Menyediakan pembayaran dari tagihan atas surat berharga

h) Melakukan kegiatan penitipan untuk kepentingan pihak lain berdasarkan suatu kontrak.

i) Melakukan penempatan dana dari nasabah kepada nasabah lainnya dalam bentuk surat berharga yang tidak tercatat dibursa efek. 
j) Membeli melalui pelelangan agunan baik semua maupun sebagian dalam hal debitur tidak memenuhi kewajibannya kepada Bank, dengan ketentuan agunan yang dibeli tersebut wajib dicairkan secepatnya.

k) Melakukan kegiatan anjak piutang, usaha kartu kredit dan kegiatan wali amanatnya.

1) Menyediakan pembiayan bagi nasabah berdasarkan prinsip bagi hasil sesuai dengan ketentuan yang ditetapkan dalam perautan pemerintah.

m) Melakukan kegiatan lain yang lazim dilakukan oleh Bank sepanjang tidak bertentangan dengan undang-undang ini dan peraturan perundang-undangan yang berlaku.Perbankan selain melakukan kegiatan usaha sebagaimana dimaksud dengan pasal 6, Bank Umum dapat pula :

n) Melakukan kegiatan dalam valuta asing dengan memenuhi ketentuan yang ditetapkan oleh Bank Indonesia.

o) Melakukan kegiatan penyertaan modal pada Bank antara perusahaan lain dibigang keuangan, seperti sewa guna usaha, modal ventura, perusahaan efek, asuransi dan lembaga kliring penyelesaian dan menyimpan, dengan memenuhi ketentuan yang ditetapkan oleh Bank Indonesia.

p) Melakukan kegiatan penyertaan modal sementara untuk mengatasi akibat kegagalan kredit, dengan syarat menarik kembali penyertaannya, dengan memenuhi ketentuan yang ditetapkan oleh Bank Indonesia.

q) Bertindak sebagai pendiri dana pensiunan dan pengurus dana pensiunan sesuai dengan ketentuan dalam peraturan perundang-undangan dana pensiunan yang berlaku.

\section{d. Kredit}

Kredit berasal dari bahasa latin credare yang berarti kepercayaan, ataucredo yang berarti saya percaya. Jadi seandainya seseorang memperoleh kredit berarti ia memperoleh kepercayaan (trust). Dengan perkataan lain maka kredit mengandung pengertian adanya suatu kepercayaan dari seseorang atau badan lainnya yaitu bahwa yang bersangkutan pada masa yang akan datang akan memenuhi segala sesuatu kewajiban yang telah diperjanjikan terlebih dahulu. Menurut UndangUndang No. 10/1998 : Kredit adalah Penyediaan uang atau Tagihan yang dapat dipersamakan dengan itu berdasarkan persetujuan atau Kesepakatan meminjam antara bank dengan pihak lain yang mewajibkan pihak peminjam untuk melunasi hutangnya .

\section{Metode Penelitian}

Penelitian ini menggunakan pendekatan kualitaif. Menurut (Creswell, 2010:4) penelitian kualitatif merupakan metode-metode untuk mengeksplorasi dan memahami makna yang oleh sejumlah individu atau sekelompok orang dianggap berasal dari masalah sosial atau kemanusiaan. Proses penelitian ini melibatkan upaya-upaya 
penting seperti mengajukan pertanyaan-pertanyaan dan prosedur-prosedur mengumpulkan data spesifik dari pertisipa, menganalisis data secara induktif melalui tema-tema yang khusus ke tema-tema yang umum, dan menafsirkan makna dari data.

\section{Hasil dan Pembahasan}

\section{a. Sejarah Singkat PT.BPR Karya Utama Jabar}

Perusahaan Daerah Bank Perkreditan Rakyat LPK Jalancagak selanjutnya disebut "Bank" didirikan di Republik Indonesia berdasarkan Surat Keputusan Bupati Kepala Daerah Tingkat II Subang Nomor 170/STAP/pe.023.3/SK/78 tanggal 1 September 1978 dengan nama PD Badan Perkreditan Pasar Jalancagak. Berdasarkan Surat Keputusan Bupati Kepala Daerah Tingkat II Subang Nomor 581/PE/32/85 tanggal 4 September 1985 diubah menjadi PD BPR Lembaga Perkreditan Kecamatan (LPK) Jalancagak. Kegiatan usaha Bank telah memperoleh izin dari Departemen Keuangan Republik Indonesia melalui Surat Keputusan Mentri Keuangan Nomor KEP-079/KM.17/1998 tanggal 18 Februari 1998 serta dari Bank Indonesia, dengan surat nomor 31/18/UBPR/ADR/Bd tanggal 14 April 1998. Dengan izin prinsip Berdasarkan Keputusan Deputi Gubernur Bank Indonesia No.13/5/KEP.DpG/2011 tanggal 12 Agustus 2011 tentang Pemberian Izin Penggabungan Usaha (Merger) PD. BPR LPK Cisalak, PD. BPR LPK Pagaden, PD. BPR LPK Purwadadi dan PD. BPR LPK Pamanukan ke dalam PD. BPR LPK Jalancagak. Menindaklanjuti Perusahaan Daerah Provinsi Jawa Barat Nomor 10 Tahun 2014 tentang perubahan Bentuk Hukum PD. BPR hasil Merger di Kabupaten Garut, Kabupaten Subang, Kabupaten Cianjur dan Kabupaten Tasikmalaya menjadi Perseroan terbatas, maka tanggal 8 April 2014 pemegang saham dan pengurus PD. BPR LPK Jalancagak telah melakukan RUPS luar biasa dalam rangka perubahan bentuk badan hokum PD. BPR LPK Jalancagak Kabupaten Subang. Dalam RUPS luar biasa tersebut pemegang saham telah memberikan persetujuan terhadap perubahan bentuk badan hokum PD. BPR LPK Jalancagak. Kemudian pada tanggal 3 Desember 2014 telah didirikan suatu Perseroan Terbatas dengan nama PT. BPR Karya Utama Jabar, sesuai dengan Akta Pendirian Perseroan Terbatas Nomor.03 tanggal 3 Desember 2014 dihadapan Asep Subrata, SH Notaris di Subang, dan telah mendapat pengesahan dari Mentri Hukum dan Hak Asasi Manusia Republik Indonesia sesuai dengan keputusan Mentri Hukum dan Hak Asasi Manusia Nomor AHU dan Hak Asasi Manusia Nomor AHU-39469.40.10.2014 Tentang Pengesahan Pendirian Badan Hukum Perseroan Terbatas PT. BPR Karya Utama Jabar, tanggal 12 Desember 2014. PT.BPR Karya Utama Jabar Cabang Pagaden dalam melakukan usahanya berdasarkan demokrasi dengan prinsip-prinsip kehati-hatian, adapun maksud dan tujuan didirikan antara lain :

1. Menunjang kelancaran penyedia permodalan di daerah pada umumnya dan pembangunan perekonomian. 
2. Menciptakan pemerataan dalam kesempatan berusaha bagi pengusaha golongan ekonomi lemah di pedesaan.

3. Menyalurkan fasilitas kredit bagi pegawai/PNS

4. Sebagai salah satu sumber pendapatan asli daerah dalam rangka pembangunan daerah.

5. Selain memberantas para pelepas uang dan pengijon, juga membantu masyarakat pedesaan dalam sector perekonomian.

Visi PT.BPR Karya Utama Jabar menjadi BPR Regional Champion yang andal dan terpercaya. Dalam rangka mewujudkan visi sebagaimana dirumuskan diatas, maka PT.BPR Karya Utama Jabar menetapkan misi sebagai berikut : 1) Turut serta dalam menggerakan roda perekonomian khususnya sector UMKM di daerah; 2) Memebrikan pelayanan prima dan professional kepada nasabah' 3) Menghasilkan keuntungan yang memuaskan bagi pemegang saham; dan 4) Meningkatkan kesejahteraan seluruh karyawan. Kegiatan Usaha PT.BPR Karya Utama Jabar. Bank Perkreditan Rakyat adalah Bank yang menerima simpanan hanya dalam bentuk deposito berjangka, tabungan, dan bentuk-bentuk lainnya yang dipersamakan dengan itu. Bagaimana lajimnya usaha Bank, Kegiatan Usaha Bank PT.BPR Karya Utama Jabar, meliputi dana tersebut pada masyarakat dalam bentuk kredit, sedangkan larangan bagi Bank Perkreditan Rakyat adalah :

a. Dilarang menerima tabungan berupa giro dan ikut serta dalam laluy lintas pembayarannya.

b. Dilarang melakukan kegiatan usaha dalam valuta asing

c. Dilarang merlakukan usaha perasuransian

d. Dilarang melakukan usaha lain diluar kegiatan usaha sebagaimana dimaksud diatas.

a. Membantu kepala bagian dana dalam mencapai target dan sasaran simpanan tabungan yang telah ditentukan.

b. Melakukan aktifitas langsung dalam kegiatan penggalangan dana menurut wilayah kerja yang telah ditentukan.

c. Melaporkan hasil dari kegiatan pengerhana dana tabungan dilapangan ke kepala bagian dana.

d. Aktif melakukan promosi dan sosialisasi.

e. Membuat laporan kemajuan penggalangan dana tabungan setiap minggun dan hasilnya.

f. Mencetak laporan nominative tabungan setiap bulan.

Fungsi :

Sub bagian dana yang melakukan aktifitas langsung kelapangan melakukan kegiatan pengarahan dana.

Tanggung Jawab :

a. Merealisasikan pencapaian target sesuai yang telah ditentukan.

b. Mampu mencapai target pengarahan dana tabungan sesuai dengan progress yang telah ditentukan.

Staf Deposito memiliki tugas pokok sebagai berikut : 
a. Melakukan promosi atau sosialisasi produk (pemasaran).

b. Mmebantu pembukuan rekening deposito dengan kelengkapan dokumen dan persyaratan yang berlaku. Fungsi :Sub bagian dana yang membantu kepala bagian dana dalam hal pengarahan dana deposito dan pinajaman pihak ketiga.

Tanggung Jawab :

Dapat mencapai target pengarahan dana deposito dan pinjaman juga pihak ketiga sesuai dengan progress yang telah ditentukan.

Manajer Pelayanan memiliki tugas pokok sebagai berikut :

a. Mewakili kepala cabang untuk melayani pihak auditor atau pihak kesternal yang berkaitan dengan keuangan perusahaan sesuai dengan keyangan perusahaan sesuai dengan limpahan wewenang yang diberikan.

b. Bertanggung jawab atas pencatatn keuangan perusahaan, pendokumentasian, beserta bukti-buktinya.

c. Bertanggung jawab atas semua bentuk dokumen yang berhubungan dengan pembelian, pembayaran, dan pendapatan.

d. Melayani, memonitor dan mengatur pembayaran transaksi keuangan dan hutang perushaan.

e. Melakukan proses sesi awal dan tutup sesi pada teller.

f. Menyelnggarakan dan memeriksa pencatatan mengenai keuangan sehubungan dengan hutang-hutang komisi, perbaikan-perbaikan kesalahan, dan modal perusahaan.

g. Melaksanakan dan memantau prinsip mengenal nasabah ( know your customer principles).

h. Menetapkan strategi pelayanan prima untuk menjaga dan meningkatkan kepuasan nasabah.

Fungsi :

a. Mengelola, melayani dan memonitor transaksi keuangan.

b. Mengkordinasi, mengarahkan dan mengawasi aktifitas teller dan customer service.

Wewenang:

a. Pemegang kunci brankas uang.

b. Menjamin ketepatan wajtu pembukaan dan penutupan.

c. Memeriksa, melegalisasi dan menjamin kebenaran transaksi kas.

d. Memberikan persetujuan penyetoran atau penarikan (otorisasi) sesuai kewenangan diatas wewenang teller.

e. Mengatur saldo kas di teller pada saat operasi.

Tanggung Jawab :

a. Menjamin kerahasiaan password milik sendiri dan tidak sharing dengan pegawai lain.

b. Ketepatan waktu dalam pemberian laporan transaksi harian kepada kacab.

c. Pelaksanaan dan pengawasan KYC dilaporkan secara berkala kepada kepala cabang.

d. Menjamin keabsahan fisik uang.

e. Memberikan pelayan yang baik, cepat dan tepat kepada nasabah. 
f. Menyampaikan saran dan usul kepada kepala cabang yang berhubungan dengan kelancaran, ketertiban dan keamanan pelayanan pengelolaan kas.

Teller memiliki tugas pokok sebagai berikut :

a. Melayani penyetoran dan pengambilan tunai.

b. Menghitung dan menyortir fisik uang tunai.

c. Melaksanakan front office yang prima.

d. Melakukan penerimaan atau pembayaran sesuai perintah bagian keuangan.

Wewenangnya adalah :

a. Melakukan akses ke computer atau data base serta mengelola data sesuai dengan prosedur dan ketentuan yang berlaku.

b. Mengambil tindakan-tindakan yang diperlukan untuk menjaga kepatuhan pelaksanaan prosedur pembukuan atau penutupan rekening dan pelayanan jasa.

c. Mengambil tindakan- tindakan yang diperlukan untuk menjaga hubungan baik dengan nasabah atau relasi.

Tanggung Jawab :

a. Terkelolanya data base nasabah file-file aplikasi yang baik.

b. Terselesaikannya masalah-masalahnya berkaitan dengan pelayanan front office.

c. Bertanggung jawab kepada bagian keuangan.

Manajer Akunting memiliki tugas pokok sebagai berikut :

a. Menyusun laporan keuangan harian, bulanan, triwulan dan tahunan.

b. Membantu sepenuhnya audit intern dan ekstern.

c. Melakukan perhitungan pph 21, 23 dan SPT tahunan.

d. Merealisasikan anggaran dan pendapatan.

e. Meningkatkan keterampilan, membimbing staff dibawahnya dalam mencapai target pelaksanaan system actual yang akurat.

Fungsi :

a. Mengelola fungsi akutansi dan administrasi sesuai dengan pedoman dan ketentuanketentuan yang berlaku.

b. Bagian yang memastikan proses transaksi akutansi telah berjalan dengan baik dan tepat.

Wewenang :

a. Melakukan pemantauan pnegeluaran biaya dengan berpedoman kepada anggaran yang telah ditentukan.

b. Melaksanakan verifikasi kepada manajemen untuk kepentingan pembuatan laporan.

Tanggung Jawab :

a. Menyajikan laporan keuangan sesuai standar akutansi.

b. Menyampaikan seluruh laporan tepat waktu.

\section{b. Pembahasan}


Kredit yang diberikan untuk tujuan meningkatkan usaha, produksi dan investasi. Kredit Produktif digunakan untuk menghasilkan barang atau jasa. Artinya Kredit Produktif digunakan untuk diusahakan sehingga menghasilkan sesuatu baik berupa barang atau jasa.

Berdasarkan Sektor Usaha Yang dibiayai :

1. Kredit Sektor Perdagangan

2. Kredit Sektor Perindustrian

3. Kredit Sektor Pertanian, Peternakan, dan Perikanan

4. Kredit Sektor Jasa Dunia Usaha

Suku Bunga Kredit Produktif tidak sama rata, tergantung kepada lamanya jangka waktu kredit, dan suku bunga kredit tergantung kebijakan Manager Kredit dan Pimpinan Cabang.

1. Untuk jangka waktu 1 tahun bunganya $1,75 \%$

2. Untuk jangka waktu 2 Tahun bunganya $2 \%$

3. Untuk jangka waktu 3 tahun bunganya $2,25 \%$

4. Untuk jangka waktu $4-5$ tahun bunganya $2,5 \%$

- Jangka Waktu Kredit Produktif :

Minimal 1 tahun (12 bulan), dan maksimal 5 tahun (60 bulan).

- Plafond Kredit Produktif

Plafond Kredir Produktif yang berjalan saat ini di PT.BPR Karya Utama Jabar Cabang Pagaden dominan dari plafond Rp. 1.000 .000 s.d Rp. 80.000.000. Karena plafond lebih dari Rp. 80.000.000 harus ada persetujuan kantor pusat.

- Jaminan Kredit Produktif :

1. SERTIFIKAT

2. $\mathrm{AJB}$

3. $\mathrm{BPKB}$

4. SPOP

5. KIKITIR

- Dokumen Yang Diperlukan Untuk Kredit Produktif :

1. Aplikasi Permohonan

2. Fotokopi KTP Suami/Istri

3. Fotokopi Kaka

4. Fotokopi Surat Nikah

5. Photo Suami/Istri

6. Rekening Listrik

7. Surat Persetujuan Suami/Istri

8. Surat Keterangan Usaha

9. Foto Usaha

10. Foto Jaminan

- Dokumen Yang Diperlukan Untuk Jaminan SERTIFIKAT, AJB, SPOP dan KIKITIR :

1. SERTIFIKAT, AJB, SPOP, KIKITIR.

2. SPPT terbaru

3. Keterangan kepemilikan dari Desa 
- Dokumen Yang Diperlukan Untuk Jaminan BPKB :

1. BPKB

2. Fotokopi STNK yang berlaku

3. Gosok No.Mesin

4. Gosok No.Rangka

Kredit Konsumtif

Kredit yang digunakan untuk keperluan pribadi misalnya keperluan konsumsi, baik pangan, sandang maupun papan. seperti Pegawai Negeri Sipil (PNS) yang mempunyai penghasilan tetap.

- Suku Bunga Kredit Konsumtif :

Untuk Suku Bunga Kredit Konsumtif adalah 1,5\%

- Jangka Waktu Kredit Konsumtif :

Untuk Jangka Waktu Kredit Konsumtif adalah 1 tahun (12 bulan) - 7 tahun (84 bulan).

- Plafond Kredit Konsumtif

Plafond Kredit Konsumtif biasanya dilihat dari sisa gaji (penghasilan).

- Dokumen yang Diperlukan Untuk Kredit Konsumtif :

1. Aplikasi Permohonan

2. SK

3. Fotokopi KTP Suami/Istri

4. Photo Suami/Istri

5. Fotokopi Kartu Keluarga

6. Fotokopi Surat Nikah

7. Surat Persetujuan Suami/Istri

8. Leger Gaji

9. Rekening Listrik

10. Surat Kuasa Pemotongan Gaji

11. Slip angsuran terakhir, apabila mempunyai pinjaman ke Bank lain Alokasi Kredit BPR

Beberapa hal yang harus diperhatikan oleh BPR, yaitu :

1. Dalam memberikan kredit, BPR wajib mempunyai keyakinan atas kemampuan dan kesanggupan debitur untuk melunasi utangnya sesuai dengan perjanjian.

2. Dalam memberikan kredit, BPR wajib memenuhi ketentuan Bank Indonesia mengenai batas maksimum pemberian kredit, pemberian jaminan, atau hal lain yang serupa, yang dapat dilakukan oleh BPR kepada peminjam atau sekelompok peminjam yang terkait, termasuk kepada erusahaan-perusahaan dalam sekelompok yang sama dengan BPR tersebut. Batas maksimum tersebut adalah tidak melebihi 30\% dari modal yang sesuai dengan ketentuan yang ditetapkan Bank Indonnesia.

3. Dalam memberikan kredit, BPR wajib memenuhi ketentuan Bank Indonesia mengenai batas maksimum pemberian kredit, pemberian jaminan, atau hal lain yang serupa, yang dapat dilakukan oleh BPR kepada pemegang saham (dan keluarga) yang memiliki 10\% atau lebih dari modal disetor, anggota Dewan Komisaris (dan keluarga), anggota Direksi (dan keluarga), pejabat BPR lainnya, serta 
perusahaan-perusahaan yang di didalamnya terdapat kepentingan pihak pemegang saham (dan keuarga) yang memiliki $10 \%$ atau

4. lebih dari modal disetor,anggota dewan komisaris (dan keluarga), anggota direksi (dan keluarga) pejabat BPR lainnya.

5. Batas maksimum tersebut tidak melebihi $10 \%$ dari modal yang sesuai dengan ketentuan yang ditetapkan Bank Indonesia.

\section{c. Proses Pemberian Kredit Secara Umum}

Secara garis besar proses pemberian kredit dapat digambarkan sebagai berikut :

1. Debitur / calon Debitur :

a. Membuat surat permohonan

b. Memenuhi kelengkapan data permohonan

2. Analis / Account Officer :

a. Memproses permohonan kredit

b. Pengumpulan data/verifikasi

c. Kunjungan calon Debitur

d. Membuat proposal hasil analisa kredit

3. Seksi legal/Appraisal :

a. Melakukan penilaian agunan

b. Membuat laporan hasil penilaian agunan

4. Seksi legal/Administrasi Kredit :

a. Menerima berkas kredit yang sudah diputus oleh komite kredit

b. Menyiapkan draft perjanjian kredit beserta dokumen pengikatannya

c. Melaksanakan penandatanganan perjanjian kredit dan pengikat

5. Kepala Bagian

Menandatangani berita hasil analisa dan hasil penialaian aguana

6. Kepala Cabang/Direksi/Dirut :

a. Memberikan keputusan kredit sebagai anggota komite kredit tertingg Menandatangani surat keputusan kredit, perjanjian kredit dan dokumen pengikatan beserta assesorisnya.

Tahapan dalam proses pemberian kredit secara umum : 


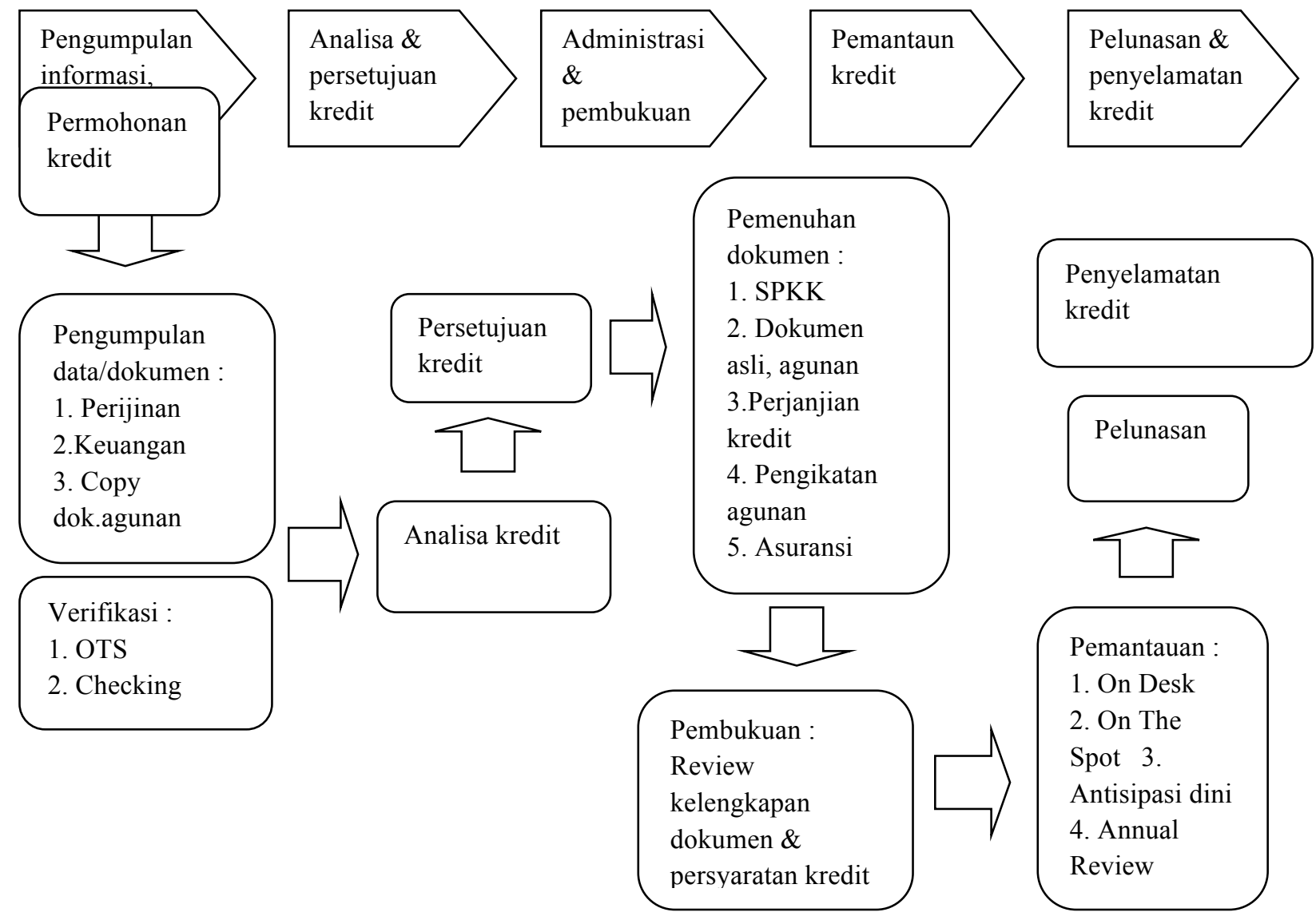

Prosedur Pemberian Kredit

1) Nasabah harus memiliki jaminan dan usaha yang layak

2) Nasabah harus berusia 21 tahun atau sudah menikah

3) Nasabah harus terbebas dari kolektibilitas dengan kategori ada tunggakan, diragukan atau macet.

4) Mengisi dan menandatangani aplikasi permohonan kredit

5) Nasabah harus tunduk kepada peraturan yang ditetapkan oleh PT.BPR Karya Utama Jabar.

Dalam melakukan penilaian permohonan kredit harus memperhatikan beberapa prinsiputama yang berkaitan dengan kondisi secara keseluruhan calon debitur, adapun prinsip penilaiandalam dunia perbankan dekenal dengan $5 \mathrm{C}$, yaitu :

1. Character

Yaitu penilaian terhadap karakter atau kepribadian calon debitur dengan tujuan untuk mengidentifikasi kualitas mental dan moral sehingga dapat memperkirakan kemungkina debitur dapat memenuhi kewajibannya, 
Identifikasi meliputi :
a. Kejujuran
b. Integritas
c. Keadilan
d. Bertanggung jawab
e. Kesederhanaan
f. Kelayakan untuk dipercaya, dll

2. Capacity

Yaitu penilaian secara subyektif tentang kemampuan debitur untuk melakukan pembayaran. Kemampuan diukur dengan :

a. Catatan perstasi debitur di masa lampau yang didukung dengan pengamatan dilapangan atas saran usaha seperti : Toko, karyawan, peralatan, pabrik dll.

b. Kemungkinan usaha survive di masa yang akan dating

3. Capital

Yaitu penilaian terhadap kemampuan modal yang dimilki oleh calon debitur yang diukur dengan posisi perusahaan secara keseluruhan oleh rasio keuangan yang penekanannya pada komposisi modalnya.

4. Collateral

Yaitu penilaian terhadap agunan yang dimiliki calon debitur dan agunan merupakan pertahanan terakhir dalam kredit apabila debitur tidak mampu membayar kewajibannya Syarat agunan kredit adalah :

a) Marketable, yaitu harus mampu dijual pada tingkat harga yang wajar dan pergerakan harganya relatif stabil.

b) Dapat diikat secara hukum, yaitu agar pihak bank dapat menjualagunan tersebut untuk membayar kewajiban hutang debitur yang tertunggak sesuai dengan prosedur hokum yang berlaku.

c) Adanya margin yang memadai, yaitu nilai agunan harus melebihi jumlah kewajiban kredit debitur, sehingga bank tidak mengalami kerugian karena agunan tidak memiliki margin yang cukup untuk menutup biaya likuidasi aguna, bungan dan kemungkinan merosotnya nilai agunan.

5. Conditions ofeconomy

Yaitu penilaian kondisi ekonomi yang terjadi di masyarakat secara spesifik dengan melihat adanya keterkaitan dengan jenis usaha yang dilakukan oleh calon debitur.Kondisi ekonomi merupakan :

1) Faktor eksteral yang berada diluar kontrol kreditur dan debitur

2) Faktor yang mempengaruhi kapasitas dan kapital dalam menentukan resiko kredit

3) Resiko kredit sangat dipengaruhi oleh perkembangan dibidang politik, sosial dan ekonomi.

Batas Maksimum Pemberian Kredit (BMPK), adalah prosentase maksimum penyediaan dana atau pemberian kredit yang diperkenankan terhadap modal Bank 
1. Pihak Terkait adalah perseorangan atau perusahaan, badan yang mempunyai hubungan pengendali dengan Bank, baik secara langsung maupun tidak langsung melalui hubungan kepemilikan, kepengurusan dan keuangan.

a. Perseorangan atau perusahaan yang merupakan pengendali Bank

b. Dewan pengawas, Direksi dan Pejabat Bank

c. Pihak yang mempunyai hubungan keluarga sampai dengan derajat kedua, baik horizontal maupun vertikal dari (Dewan Pengawas, Direksi, dan Pejabat Eksekutif Bank).

2. Pihak Tidak Terkait adalah perseorangan atau perusahaan,yang tidak mempunyai hubungan atau keterkaitan pengendali dengan Bank.

3. Perhitungan BMPK :

a.Bagi pihak terkait baik sebagai 1 (satu) peminjam atau kelompok peminjam ditetapkan setinggi tingginya sebesar 10\% dari Modal Bank atau sesuai dengan ketentuan Bank Indonesia.

b Bagi pihak tidak terkait baik sebagai 1 (satu) peminjam atau kelompok peminjam ditetapkan setinggi-tingginya sebesar 20\% dari Modal Bank atau sesuai dengan ketentuan Bank Indonesia.

Memproses pengajuan kredit dan menyimpan berkas-berkasnya.

1) Menerima pengajuan permohonan kredit

2) Mengecek kelengkapan berkas administrasi yang disyaratkan dalam pengajuan kredit

3) Melakukan survey ke lokasi atau kontak dengan pihak-pihak eksternal untuk pengumpulan data atau informasi tambahan terkait penyusunan analisa kredit

4) Melakukan cek atas agunan yang digunakan untuk pengajuan kredit

5) Menyusun analisa permohonan kredit sesuai batas kewenangan

6) Melakukan pemantauan atau pembinaan kepada debitur

7) Meyimpan dan mengelola berkas-berkas debitur kredit di KCP

8) Monitoring kredit kolektibilitas 1 dan 2

Permasalahan yang dihadapi dalam proses transaksi adalah :

a. Tingkat suku bunga kredit cukup tinggi jika dibandingkan dengan Bank-Bank umum lainnya sehingga menjadi permasalahan kurangnya permohonan kredit, sehingga harus ekstra kerja keras dalam mendapatkan nasabah baru.

b. Kredit tidak lepas dari kolektibilitas atau kredeit macet, kemacetan angsuran nasabah adalah hal yang paling sering dihadapidalam kredit, selain karakteristik konsumen yang sulit untuk ditebak juga turun dan naiknya usaha nasabah adalah hal yang patut untuk diperhatikan karena dua hal tersebut yang menjadi tingkat kemacetan angsuran meningkat.

c. Debitur selalu menginginkan proses permohonan kredit yang diajukannya cepat di acc atau dicairkan.

d. Kurangnya atau tidak lengkap persyaratan dokumen kredit. 
Volume 1 Issue 1, Juni 2019

http:/ / ejournal.unsub.ac.id/index.php/keuangan

\section{Kesimpulan}

Proses pemberian kredit di PT.BPR KARYA UTAMA JABAR CABANG PAGADEN, dasarnya telah sesuai dengan ketentuan-ketentuan perkreditan di lembaga perbankan dan pada tahap penilaian kelayakan kredit yang pada umumnya menggunakan prinsif 5C.

Persyaratan-persyaratan kredit bagi debitur, persyaratan mengenai identitas dan dokumen-dokumen atau perusahaan merupakan persyaratan yang mutlak harus dipenuhi. Apabila persyaratan tersebut tidak dipenuhi maka permohonan kredit tersebut akan dikembalikanuntuk dilengkapi terlebih dahulu, karena hal tersebut guna jika kredit tersebut macet dan tidak bertanggungjawab.

Prosedur adalah rangkaian cara yang disatukan dan menjadi pola yang tetap dalam peaksanaan setiap pekerjaan dan menjadi acuan bagi setiap pegawai untuk melaksanakan pekerjaan baik pada organisasi pemerintahan maupun organisasi swasta. Prosedur dalam oermohonan kredit telah sesuai dengan peraturan PT.BPR KARYA UTAMA JABAR CABANG PAGADEN.

Berdasarkan hasil pengamatan dan penelitian selama melaksanakan praktek terdapat beberapa saran yang berhubungan dengan kekurangan-kekurangan pada proses pemberian kredit, guna untuk kelangsungan dan kenyaman para debitur. Saran tersebut diantaranya : penilaian kelayakan calon nasabah, yang ada pada prinsip 5C terutama poin pertananian yaitu Character adalah hal yang paling utama dan tidak terburu-buru menyimpulkan karakter calon Nasabah. Untuk memberikan kredit sebaiknya lebih berhati-hati, jangan sampai membuat kesalahan. Karena akan mengakibatkan kredir macet. Nasabah guna memperkecil atau meminimalisir terjadinya kredit macet. Dalam prosedur permohonan kredit seharunya jangan terpaku dalam persyaratan kredit, akan tetapi pihak Bank harus flexible dalam melatyani nasabah karena tidak sedikit nasabah tidak memiliki bnyak waktu harus mengurus usahanya, dengan demikian akan bersaing dengan Bank-Bank lain dalam pelayanan kredit.

\section{Referensi}

Kasmir. 1998. Bank dan Lembaga Keuangan Lainnya. Jakarta: PT. RajaGrafindo Persada.

Lukman Dendawijaya. 2001. Manajemen Perbankan. Jakarta: Ghalia Indonesia.

Ruddy Tri Santoso. 1996. Kredit Usaha Perbankan. Yogyakarta: Andi

Suhardjono. 2003. Manajemen Perkreditan Usaha Kecil dan Menengah. Yogyakarta: Unit Penerbit dan Percetakan (UPP0 AMP YKPN.

Sumadi Suryabrata. 2004. Metodologi Penelitian. Jakarta: PT RajaGrafindo Persada

Thomas Suyatno, H.A. Chalik, Made Sukada, C. Titom Yunianti Ananda, Djuhaepah T. Marala. 1995. Dasar-Dasar Perkreditan. Jakarta: Gramedia Pustaka Utama. 


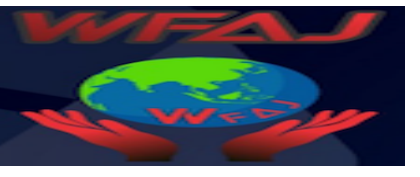

Volume 1 Issue 1, Juni 2019

http://ejournal.unsub.ac.id/index.php/keuangan

Veithzal Rivai dan Andria Permata Veithzal. 2006. Credit Management Handbook, Teori, Konsep, Prosedur dan Aplikasi Pnaduan Praktis Mahasiswa, Bankir dan Masalah. Jakarta: PT. RajaGrafindo Persada.

Undang-Undang Republik Indonesia Nomor 7 Tahun 1992 Tentang Jenis-Jenis Perbankan

Undang-Undang Republik Indonesia Nomor 10 Tahun 1998 Tentang Perbankan

SOP (Standar Operation Prosedur) PT. BPR Karya Utama Jabar 